\title{
Educational and research activity of the Department of Operative Techniques and Surgical Research, Institute of Surgery at the Medical and Health Science Center, University of Debrecen in Hungary
}

\author{
Norbert Nemeth', Istvan Furka', Iren Miko ${ }^{\text {III }}$ \\ IPhD, Associate Professor, vice-chair, honorary member of the SOBRADPEC. \\ IIPhD, Emeritus Professor, former chair (1986-2000), head of Microsurgical Education and Training Center of the Department. \\ IIIPDD, Full Professor, chair (2000-2013).
}

\section{Introduction}

Since 2007 our department could establish a very fruitful and important connection with the SOBRADPEC by the first author of this paper, thanking especially to Professor Saul Goldenberg and to Professor Edna F.S. Montero. By these connections and when attending the unforgettable congresses in Cuiaba (2007), Ribeirao Preto (2011) and in Belem (2012), we could exchange scientific and organizational concerns ${ }^{1-4}$.

With Prof. Montero, the relationship is existing since 1998, where the second and third author have met her in London/Ontario at the Congress of the International Society for Experimental Microsurgery (ISEM), that was organized by Prof. Robert Zhong ${ }^{5}$. Also the good contact had been continued later on the consecutive ISEM Congresses (2000 Catania, 2002 San Diego, 2004 Debrecen, 2006 Montreal, 2008 Shanghai, 2010 São Paulo and 2012 Timisoara $)^{6-10}$. Under the aegis of the ISEM, of which President was Prof. Montero (2010-2012), the Brazilian connection always presented a very important value for us.

Based upon the invitation by Professor Saul Goldenberg we have the honour to introduce the educational and research activity of our department, with the motto: experimental surgery is a big, international family.

\section{Brief history of the Department}

The University of Debrecen Medical and Health Science Center Department of Operative Techniques and Surgical Research (http://www.surg.res.dote.hu) deals with education and surgeryrelated basic- and applied research. The Department is one of the departments of the Institute of Surgery, with independent finance functioning and stuffing structure, as well as with own educational and research activity ${ }^{11-12}$.
The predecessor of the Department, The Institute of Surgical Anatomy and Operative Techniques, was established in the academic year of 1950/51, of which first director was Dr. Denes Nagy. One year later, the Institute was directed by Prof. Dr. Gyorgy Bornemisza between 1952-1986. The name of the Institute from 1972 was Institute of Experimental Surgery. Between 19862000 the head of the Institute was Prof. Dr. Istvan Furka, and from 2000 Prof. Dr. Iren Miko. The name of the Institute in 2000 was changed to Institute of Operative Techniques and Surgical Research, than in 2004, by forming the integrated Institute of Surgery, it became its' independent Department.

The Department of Operative Techniques and Surgical Research is located in two buildings on $\sim 1.300$ square meters.

The Microsurgical Education and Training Centre (head: Prof. Istvan Furka) provides seven training stages with seven microscopes, with camera and photo as well as with DVD recording systems. In three operating theatres on total of six operative tables we provide the room for practices on biomodels or on anesthetized living large animals by accredited educational programs. Our Hemorheological Research Laboratory (head: Norbert Nemeth) provide a wide range of special rheological measurements in a unique combination being adapted for experimental surgery on various animal species: from murine to porcine models.

Keeping and valuing the traditions and scientific and educational treasure, museums and permanent public exhibitions have been settled in the department: Museum of Surgical Suture Materials, Exhibition of Surgical Staplers' History, Sun Lee Microsurgical Museum, Memorial Place for Janos Veres (inventor of the Veres-needle that is used for laparoscopic interventions worldwide), Extra Gallery.

Education, research and activities in the service of clinical practices: are our aims. 


\section{Main educational programs}

The Department has a wide range of educational activity and programs. On graduate level, we teach main compulsory subjects, compulsory and freely chosen elective courses (Table 1) both in Hungarian and English Program.

TABLE 1 - Subjects and courses of the Department at graduate level in Faculty of Medicine, Faculty of Dentistry and Faculty of Pharmacy.

\begin{tabular}{|c|c|c|c|c|}
\hline Faculty & English title of the subject/course & Type & Year & Hours \\
\hline \multirow{6}{*}{ General Medicine (GM) } & „Basic Surgical Techniques” & compulsory & III & $\begin{array}{l}15 \mathrm{~h} \text { lectures, } \\
30 \mathrm{~h} \text { seminars/ practices }\end{array}$ \\
\hline & „Surgical Operative Techniques” & $\begin{array}{l}\text { compulsory } \\
\text { choosen }\end{array}$ & III, IV & $\begin{array}{l}4 \mathrm{~h} \text { lectures, } \\
8 \mathrm{~h} \text { practices }\end{array}$ \\
\hline & $\begin{array}{c}\text { „Basic microsurgical training. Introduction to } \\
\text { microsurgery” }\end{array}$ & $\begin{array}{l}\text { compulsory } \\
\text { choosen }\end{array}$ & IV & $\begin{array}{l}2 \mathrm{~h} \text { lectures, } \\
10 \mathrm{~h} \text { practices }\end{array}$ \\
\hline & „Basic Laparoscopic Surgical Training” & $\begin{array}{l}\text { compulsory } \\
\text { choosen }\end{array}$ & V & $\begin{array}{l}3 \mathrm{~h} \text { lectures, } \\
12 \mathrm{~h} \text { practices }\end{array}$ \\
\hline & „Surgical biomaterials” & $\begin{array}{l}\text { compulsory } \\
\text { choosen }\end{array}$ & V & $12 \mathrm{~h}$ \\
\hline & „Basics of hemorheology” & freely choosen & IV, V & $10 \mathrm{~h}$ \\
\hline $\begin{array}{c}\text { GM- Biomedical Laboratory } \\
\text { and Diagnostic Imaging Analyst } \\
\text { Program }\end{array}$ & „Basics of Animal Experimentation” & compulsory & III & $\begin{array}{c}14 \mathrm{~h} \text { lectures, } \\
28 \mathrm{~h} \text { seminars/practices }\end{array}$ \\
\hline Dentistry & „Basic Surgical Techniques” & compulsory & III & $\begin{array}{l}5 \mathrm{~h} \text { lectures, } \\
13 \mathrm{~h} \text { seminars/ practices }\end{array}$ \\
\hline Pharmacy & „Basic knowledge of surgical biomaterials” & $\begin{array}{l}\text { compulsory } \\
\text { choosen }\end{array}$ & IV & 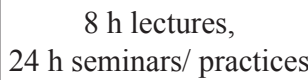 \\
\hline
\end{tabular}

On postgraduate level, we organize Ph.D. courses, and within the confines of the Resident Education Program, besides the nine accredited courses on the Continuous Postgraduate Educational Program with special trainings, we have the one-month skill training, which is obligatory for every resident of the operative medicine (which had been a three-week long "Operative Techniques Training" course previously) (Table 2). 
Educational and research activity of the Department of Operative Techniques and Surgical Research, Institute of Surgery at the Medical and Health Science Center, University of Debrecen in Hungary

TABLE 2 - Courses of the Department at postgraduate level.

\begin{tabular}{|c|c|c|}
\hline $\begin{array}{l}\text { Education } \\
\text { form }\end{array}$ & English title of the postgraduate course & Duration / hours \\
\hline $\begin{array}{l}\text { Resident } \\
\text { Program }\end{array}$ & $\begin{array}{c}\text { „Basic surgical practices”/,,Surgical skill training” } \\
\text { (mentors: Prof. Dr. Istvan Furka, Prof. Dr. Iren Miko, Dr. Norbert Nemeth) }\end{array}$ & $\begin{array}{l}\text { till 2012: } 3 \text { weeks, } \\
\text { from 2012: } 1 \text { month }\end{array}$ \\
\hline \multirow{7}{*}{ Ph.D. Programs } & $\begin{array}{l}\text { „Basics of microsurgery for biomedical research" } \\
\text { (coordinator: Prof. Dr. Istvan Furka) }\end{array}$ & $15 \mathrm{~h}$ \\
\hline & „Microsurgical techniques” (coordinator: Prof. Dr. Iren Miko) & $15 \mathrm{~h}$ \\
\hline & $\begin{array}{c}\text { "Basic surgical techniques for research on laboratory animals" } \\
\text { (coordinator: Dr. Katalin Peto) }\end{array}$ & $15 \mathrm{~h}$ \\
\hline & „Surgical biomaterials” (coordinator: Prof. Dr. Iren Miko) & $12 \mathrm{~h}$ \\
\hline & $\begin{array}{l}\text { „Experiences on preclinical (animal experimentation) phase of pharmaceutical developments with } \\
\text { special focus on quality control” (coordinator: Dr. Ildiko E. Takacs) }\end{array}$ & $12 \mathrm{~h}$ \\
\hline & $\begin{array}{l}\text { „Hemorheological and microcirculatory relations } \\
\text { of ischemia-reperfusion” (coordinator: Dr. Norbert Nemeth) }\end{array}$ & $14 \mathrm{~h}$ \\
\hline & $\begin{array}{c}\text { „Laboratory Animal Science and Experimental Design” } \\
\text { (coordinator: Prof. Dr. Istvan Furka) }\end{array}$ & $80 \mathrm{~h}$ \\
\hline \multirow{9}{*}{$\begin{array}{l}\text { Continuous } \\
\text { Postgraduate } \\
\text { Educational } \\
\text { Program }\end{array}$} & $\begin{array}{c}\text { „Surgical operative techniques. Basic interventions in surgery” } \\
\text { (Announced for general surgeons, pediatric surgeons, gynecologists, urologists, traumatologists, } \\
\text { orthopedic surgeons) }\end{array}$ & $\begin{array}{l}2 \text { days ( } 4 \text { h lectures, } \\
10 \mathrm{~h} \text { practices) }\end{array}$ \\
\hline & $\begin{array}{c}\text { „Basic Microsurgical Training. Introduction to Microsurgery" } \\
\text { (Announced for general surgeons, pediatric surgeons, gynecologists, urologists, traumatologists, } \\
\text { orthopedic surgeons, heart surgeons, neurosurgeons, plastic and reconstructive surgeons, oto- } \\
\text { laryngologists) }\end{array}$ & $\begin{array}{l}2 \text { weeks ( } 8 \text { h lectures, } \\
72 \mathrm{~h} \text { practices })\end{array}$ \\
\hline & $\begin{array}{l}\text { „Laparoscopic cholecystectomy. } \\
\text { Basic laparoscopic surgical training in experimental animals” } \\
\text { (Announced for general surgeons) }\end{array}$ & $\begin{array}{l}1 \text { day }(2 \mathrm{~h} \text { lectures, } \\
6 \mathrm{~h} \text { practices })\end{array}$ \\
\hline & $\begin{array}{c}\text { "Special laparoscopic surgical interventions on experimental animals. Advanced courses in } \\
\text { laparoscopic surgery" } \\
\text { (Announced for general surgeons) }\end{array}$ & $\begin{array}{l}1 \text { day }(2 \mathrm{~h} \text { lectures, } \\
6 \mathrm{~h} \text { practices })\end{array}$ \\
\hline & $\begin{array}{l}\text { „Special laparoscopic urological interventions on experimental animals. Advanced courses in } \\
\text { laparoscopic urological surgery." } \\
\text { (Announced for urologists) }\end{array}$ & $\begin{array}{l}1 \text { day }(2 \mathrm{~h} \text { lectures, } \\
6 \mathrm{~h} \text { practices })\end{array}$ \\
\hline & $\begin{array}{c}\text { „Latest information on surgical suture materials” } \\
\text { (Announced for general surgeons, pediatric surgeons, gynecologists, urologists, traumatologists, } \\
\text { orthopedic surgeons, heart surgeons, neurosurgeons, plastic and reconstructive surgeons, oto- } \\
\text { laryngologists) }\end{array}$ & $\begin{array}{l}1 \text { day ( } 3 \text { h lectures, } \\
5 \text { h practices) }\end{array}$ \\
\hline & $\begin{array}{l}\text { "Basic surgical techniques for family doctors" } \\
\text { (Announced for family doctors) }\end{array}$ & $\begin{array}{l}2 \text { days ( } 4 \text { h lectures, } \\
12 \mathrm{~h} \text { practices })\end{array}$ \\
\hline & $\begin{array}{l}\text { "Surgical interventions under emergency and catastrophe circumstances" (Announced for } \\
\text { anesthesiologists and intensive care specialists, oxyologists, family doctors) }\end{array}$ & $\begin{array}{l}2 \text { days ( } 5 \text { h lectures, } \\
11 \text { h practices })\end{array}$ \\
\hline & $\begin{array}{l}\text { „Application of surgical tissue adhesives and bioplasts in surgical interventions" } \\
\text { (Announced for general surgeons, pediatric surgeons, gynecologists, urologists, traumatologists) }\end{array}$ & $\begin{array}{l}1 \text { day ( } 4 \text { h lectures, } \\
6 \text { h practices) }\end{array}$ \\
\hline
\end{tabular}


In addition, we regularly take part in refresher courses and workshops announced by the Institute of Surgery.

\section{Fields of research interest}

The current major research fields of the Department are:

1. Parenchymal organ preservation techniques (especially spleen-salvaging methods: special spleen resection technique and spleen autotranplantation method - which has a three-decade tradition in the Department).

2. Ischemia-reperfusion of different organs and tissues (limbs, liver, kidney, small intestine, muscle-flap, testicles), also related to vascular interventions (vascular anastomoses, creating artificial shunts, implanting vascular grafts).

3. Comparative hemorheological investigations (interspecies and gender differences of hemorheological parameters of experimental/laboratory animals), methodology, adaptation

4. In addition, we take part in different clinical studies with the special instruments of our Hemorheological Research Laboratory.

In the last decades over 300 full articles, dozen of books, over 150 Student Scientific theses and graduation theses, $10 \mathrm{Ph} . \mathrm{D}$ dissertations, two habilitations and dozens of scientific grants are the indicators of the scientific activity. Besides these, numerous leader functions can be linked to our core staff members, as a great honor for us and for the whole department (mains: Hungarian Surgical Society, Hungarian Society for Hemorheology, Hungarian Laboratory Animal Society, European Society for Surgical Research, International Society for Clinical Hemorheology, International Society for Experimental Microsurgery).

Everything is in the service of enforcing the relation between research work and clinical practice - and always being open for national and international co-operations.

In the Announcement of the $24^{\text {th }}$ Congress of the Experimental Surgical Section of Hungarian Surgical Society, that will be held in Debrecen, Hungary, on 13-15 June, 2013, the following thoughts were declared: „,...We put a premium on the meetings of clinicians' and experts' specialized with research, stimulating discussions and establishing of much more, more closer co-operations, as we believe that this is one of main goal of the experimental surgery. We believe that altogether with the traditions, honoring the masters, supporting talented youth, tight collaboration with the clinicum, the committed education and the devoted research can improve the surgery and the experimental surgery in the further decades, too. “-Norbert Nemeth (President of the Congress), Iren Miko (Honorary President of the Congress) and Istvan Furka (Perpetual Honorary President of the Congress).

\section{References}

1. Goldenberg S. Discurso proferido na sessão de abertura do $X$ Congresso da Sobradpec, em Cuiabá-MT, no dia 28 de abril de 2007. Acta Cir Bras. 2007;22:238.

2. Aguilar-Nascimento JE. SOBRADPEC and Acta Cirurgica Brasileira: 20 years assisting the development of surgical research in Brazil. Acta Cir Bras. 2007;22(Suppl. 1):1.

3. Goldenberg S. Reflections about the parallelism between experimental surgery and music. Acta Cir Bras. 2007;22:330-1.

4. Castro e Silva O, Santana ACDA. XII National Congress of Experimental Surgery, IX Forum of Scientific Initiation, Workshop on Organ Transplantation. Acta Cir Bras. 2011;26 (Suppl. 2):1-2.

5. Zhong R, Lee S. Recent advances in experimental microsurgery: the 4th congress of the international society for experimental microsurgery (ISEM). Microsurgery. 1999;19:305.

6. Di Cataldo A, Puleo S, Zhong R. Introduction special issue: frontiers in microsurgery: Recent advances in experimental microsurgery. Microsurgery. 2001;21:117.

7. Chen H, Qian S, Gassel HJ. Frontiers in microsurgery: Recent advances in experimental microsurgery. Microsurgery. 2003;23:411.

8. Miko I, Furka I, Nemeth N. Frontiers in microsurgery: the $7^{\text {th }}$ Congress of the International Society for Experimental Microsurgery. Microsurgery. 2006;26:1-3.

9. Klein I, Gassel HJ. Frontiers in experimental microsurgery: The eighth congress of the International Society for Experimental Microsurgery,Montreal, Canada July 16-19, 2006. Microsurgery. 2007;27:212-3.

10. Nemeth N. Crossroads of Experimental Microsurgery. A Preface to the Special Issue of the $9^{\text {th }}$ Congress of the International Society for Experimental Microsurgery. Microsurgery. 2010;30:253-5.

11. Kapusz N, Petrovics A, Vasarhelyi F. Kilencvenéves a debreceni orvosképzés. Debreceni Egyetem Orvos- és Egészségtudományi Centrum, Debrecen, 2008.

12. Miko I, Brath E, Peto K, Lesznyak T, Nemeth N, Furka A, Takacs EI, Furka I. Graduate education of „Basic Surgical Techniques” between 1987-2007 at the Department of Operative Techniques and Surgical Research, University of Debrecen. Br J Surg. 2008;95(S6):85.

\section{Correspondence:}

Norbert Nemeth M.D., Ph.D.

Department of Operative Techniques and Surgical Research

Medical and Health Science Center

University of Debrecen

H-4032 Debrecen, Nagyerdei krt. 98.

P.O. Box: 21. Hungary

Phone/Fax: +36-52-416-915

nemeth@med.unideb.hu

Received: January 23, 2013

Review: March 21, 2013

Accepted: April 22, 2013

Conflict of interest: none

Financial source: none 